\title{
ENVIRONMENTAL CONDITIONS OF SHELLY PHOSPHORITE ACCUMULATION IN THE RAKVERE PHOSPHORITE REGION, NORTHERN ESTONIA
}

\author{
Heljo HEINSALU ${ }^{a}$, Viive VIIRA ${ }^{a}$, and Rein RAUDSEP ${ }^{b}$
}

a Eesti Teaduste Akadeemia Geoloogia Instituut (Institute of Geology, Estonian Academy of Sciences), Estonia pst. 7, EE-0100 Tallinn, Eesti (Estonia)

b Eesti Geoloogiakeskus (Geological Survey of Estonia), Pikk 67, EE-0001 Tallinn, Eesti (Estonia)

Presented by V. Puura

Received January 21, 1994; accepted March 25, 1994

Abstract. The established conodont zones in the Cambrian-Ordovician boundary beds in northern Estonia serve as a basis for the interpretation of the succession of changes in the facies conditions of sedimentation. The facies maps compiled by time intervals correspond to the Westergaardodina, Cordylodus andresi, C. proavus, C. lindstromi, and C. rotundatus-C. angulatus conodont zones. Phosphorite accumulation was the most intensive during the $C$. proavus time. The rugged topography of the underlying Lower Cambrian Tiskre and Vaki formations on the territory of the Rakvere phosphorite region was of great significance in the phosphorite accumulation. At the initial stages of phosphorite accumulation three bottom swells (islands) existed there. The most intensive piling up of phosphorite was related to these swells. They coincide in direction with the present Aseri and Ahtme disturbance zones.

Key words: Cambrian-Ordovician boundary beds, shelly phosphorite, Estonia.

The Rakvere phosphorite region (RPR) is situated in northeastern Estonia; it comprises the Toolse and Aseri deposits in its northern part and the Rakvere deposit in its southern part. The latter is subdivided into large areas, the most important among them being the Assamalla, Rägavere, and Kabala areas (Fig. 1). The lithostratigraphy of the phosphoritebearing rocks and correlation of the sequences of the RPR were suggested by Heinsalu and Raudsep (1993).

The present paper aims mostly at a biostratigraphic subdivision of these sediments and lithofacies analysis by the time intervals established.

The RPR is a kind of juncture in the lithologic-stratigraphic structure of the phosphate-bearing beds adjoining the Cambrian-Ordovician boundary. All the distinguished members of the Kallavere Formation occurring to the west (Maardu and Suurjõgi members) as well as to the east (Rannu Member) of the RPR are represented there. In the northern part of the RPR the Suurjõgi and Rannu members are overlain by the 
Katela Member, which gradually goes over into the Orasoja Member approximately to the east of Aseri. Apart from the above five members of the Kallavere Formation, the phosphate-bearing beds of the RPR include also the Tsitre Formation (Figs. 2, 3).

The phosphate-bearing beds in the RPR are underlain by sediments of the Lower Cambrian Tiskre (in the north) and Vaki (in the south) formations.

After a long break from the early to late Cambrian, sedimentation did not start simultaneously on the whole RPR territory. Of great importance for the accumulation of phosphate-bearing sediments in the RPR was the rugged topography of the underlying Tiskre and Vaki sediments. At the initial stages of the accumulation of phosphate-bearing sediments the observed region comprised three elevated areas (bottom swells). Two northern ones constituted rather large, southwest-northeast-directed nonsedimentation areas (islands?) with a dissected coastline, called Rakvere - Aseri and Väike-Maarja-Tudu swells. The third, yet unnamed swell, has been established in the southernmost part of the studied region. The bulk of it is obviously located to the south of the region described.

The biostratigraphic subdivision of the phosphate-bearing strata, which serves as a basis for the lithofacies analysis, is mainly based on the results of conodont studies (V. Viira). Scarce finds of Obolus apollinis (identifications by I. Puura and L. Popov) and acritarch data by I. Paalits have also been used.

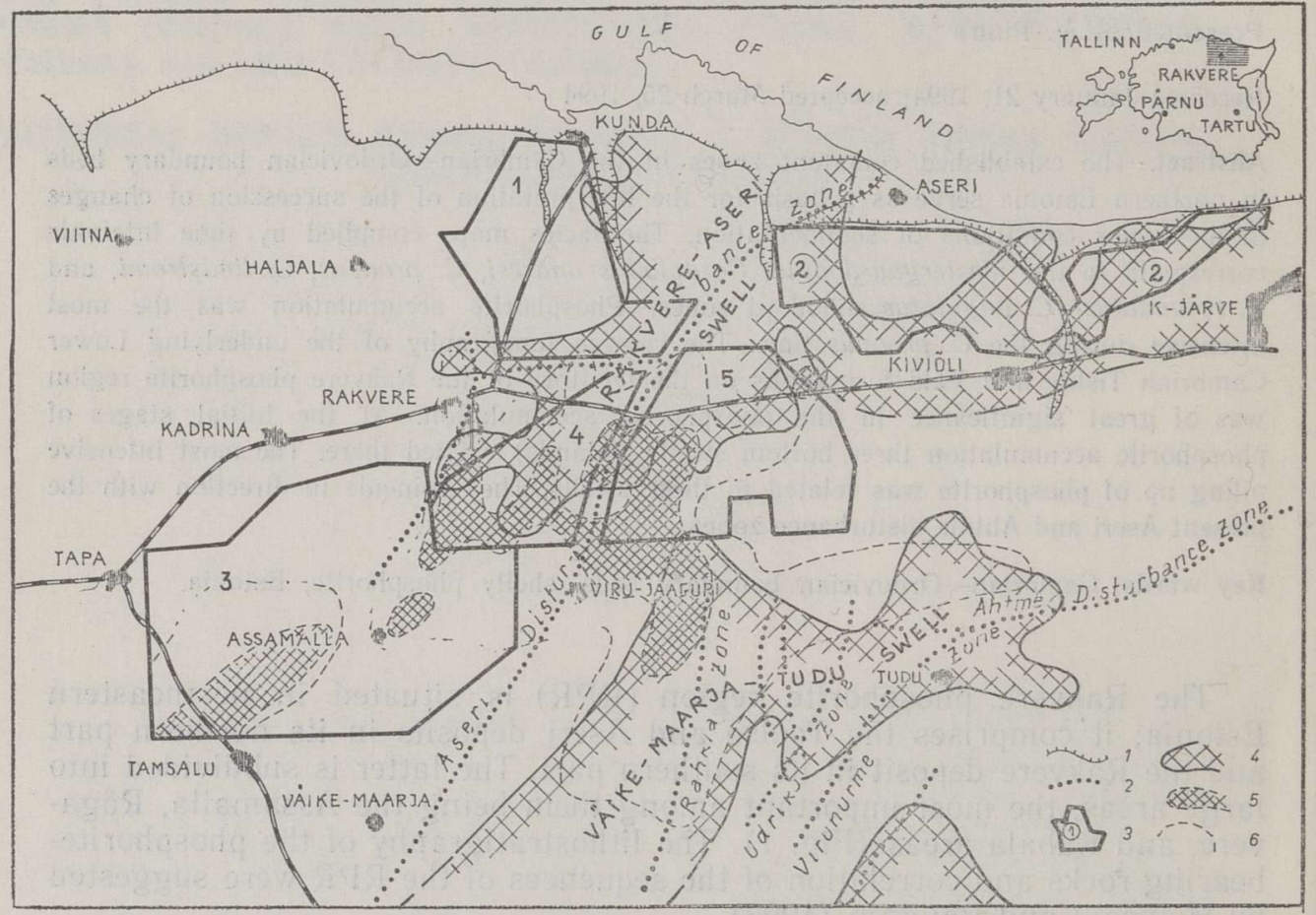

Fig. 1. Areas of maximum phosphorite accumulation and the location of phosphorite deposits in the Rakvere phosphorite region.

1 North-Estonian klint; 2 tectonic disturbance zones; 3 phosphorite deposits and areas:

1. Toolse and 2 Aseri deposits, 3 Assamalla, 4 Rägavere, and 5 Kabala areas; 4 bottom swells (islands) at early stages of the deposition of phosphate-bearing sediments; 5 areas of maximum phosphorite accumulation (thickness of the phosphorite bed over $6 \mathrm{~m}$ ); 6 areas of phosphorite beds with a thickness of $4-6 \mathrm{~m}$. 


\section{CONODONTS}

In the studied sections (Vihula, Toolse, Aseri, Saka outcrops, and P-2162, P-2087, P-2176, P-2290 boreholes; Fig. 3) conodonts are of sporadic distribution. They are the most diverse in the Toolse and Saka sections (Kaljo et al., 1986). In the borehole sections of the southern area of the RPR conodonts have been recorded from some levels only.

The oldest conodonts were identified from the Upper Cambrian of the Saka section. These are paraconodonts Westergaardodina cf. bicuspidata, Prooneotodus cf. gallatini, and Furnishina sp. All of them are representatives of the Westergaardodina Zone.

In the next zone, the Cordylodus andresi Zone, the euconodonts, s. c. real conodonts, made their first appearance. The zone has been established in Vihula and Toolse sections. Apart from the index species, it comprises C. primitivus, C. viruanus, Eoconodontus notchpeakensis, the transitional species W. cf. bicuspidata, $F$. cf. furnishi, $P$. cf. gallatini, coming from the Upper Cambrian, and even the protoconodont Phakelodus tenuis, mainly restricted to the Cambrian.

The index species of the $\boldsymbol{C}$. proavus Zone is morphologically closely connected with $C$. andresi. The zone is established in the Vihula, Toolse, and Saka sections, containing besides the index species C. caboti, C. viruanus, E. notchpeakensis, rarely Westergaardodina sp., Furnishina $\mathrm{sp}$., and in the Toolse section also C. intermedius.

The next zone is the $\boldsymbol{C}$. lindstromi Zone, established in the Toolse, Saka, and Aseri outcrops and P-2162, P-2087, and P-2176 borehole sections. Other conodonts are represented by $C$. proavus, C. intermedius, $C$. prion, $C$. drucei, and E. notchpeakensis. The Saka section has yielded the first specimens of Oneotodus altus, forming morphological transitions with the species E. notchpeakensis and replacing the latter in higher strata. In one sample from the P-2176 borehole section C. lindstromi occurred together with Drepanodus sp., which has probably come here from higher layers.

The evolutionary lineage of the genus Cordylodus ends up in the C. rotundatus - $C$. angulatus Zone. The index species of the zone have been established in the Saka and Aseri sections. Besides them, here occur C. lindstromi, C. prion, O. altus, rarely C. proavus, all transitional from lower strata. The Toolse section has also yielded Iapetognathus sp. In the P-2290 borehole section the upper part of the Rannu Member contains also $C$. rotundatus and $C$. aff. angulatus, occurring together with conodonts of the Upper Tremadoc Drepanoistodus deltifer Zone. This co-occurrence may have two reasons. Firstly, this level itself may be the $D$. deltifer Zone, characterized by the occurrence of Cordylodus sp. However, this version seems unlikely. Secondly, these species might have been carried into this interval from the higher Varangu Formation. This explanation seems quite truthful. In addition to the zonal species, it contains Drepanodus arcuatus, Paroistodus numarcuatus, and Scolopodus sp. As a rule, the $D$. deltifer Zone is subdivided into $D$. deltifer pristinus (lower) and $D$. deltifer deltifer (upper) subzones. The specimens of $D$. deltifer from the P-2290 borehole section cannot be identified up to the subspecies level on the basis of the material available.

However, $D$. deltifer pristinus was identified in the Toolse Member of the Saka section, where it is concurrent with $C$. rotundatus, $C$. angulatus, $C$. prion, and $O$. altus.

Below we shall present the distribution of the sediments corresponding to the conodont zones distinguished. 


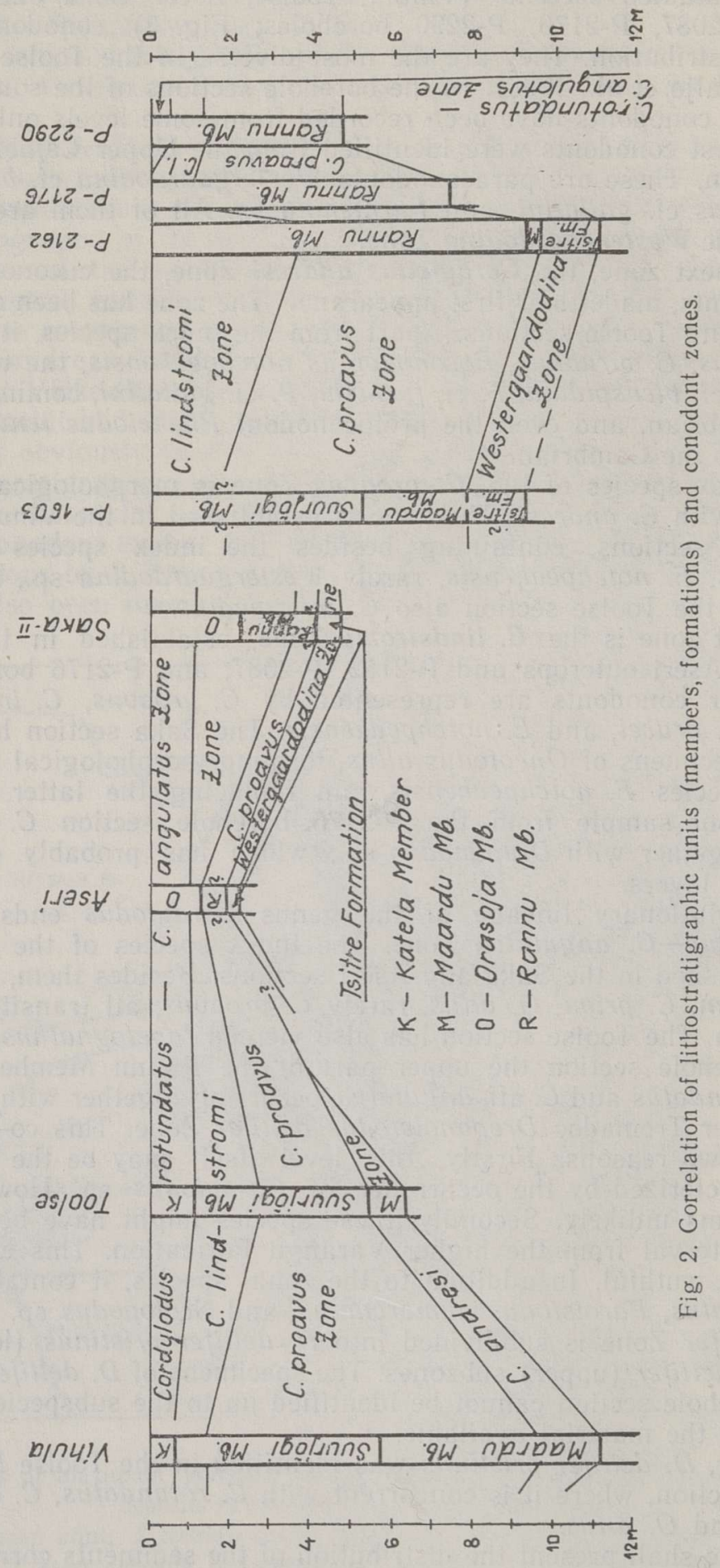


VIHULA

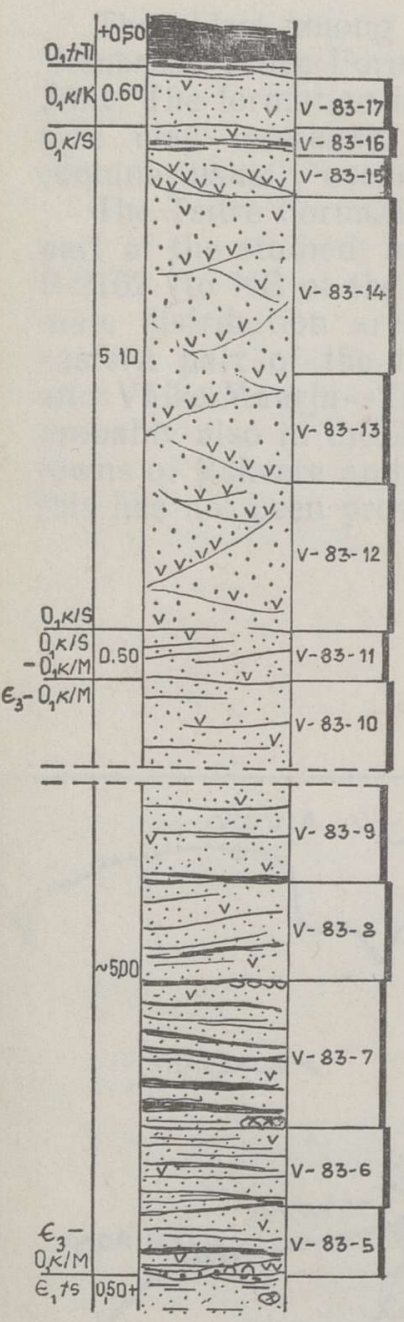

TOOLSE

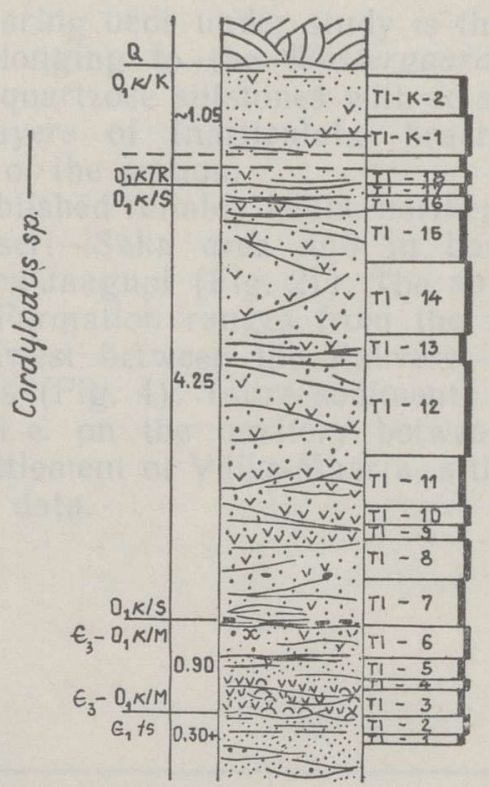

का
ASERI

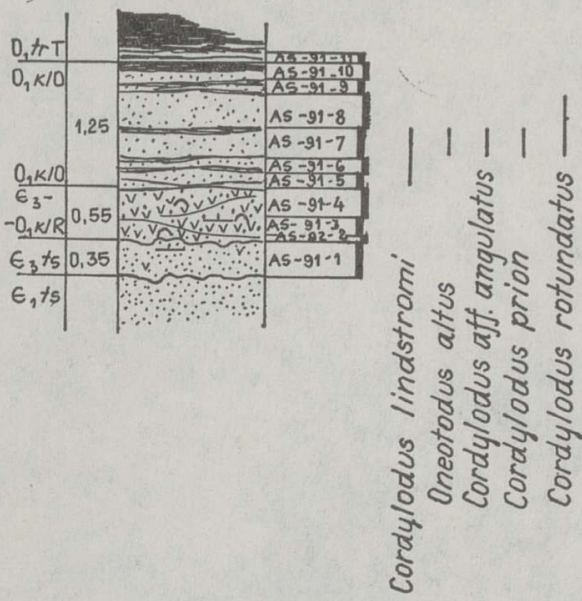

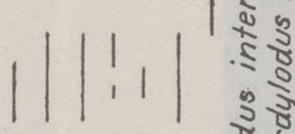

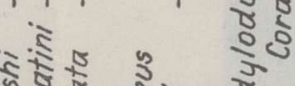

2. 2505

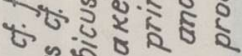

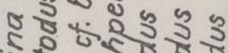

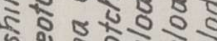

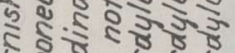

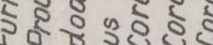

2
2
2
2
2
SAKA-II

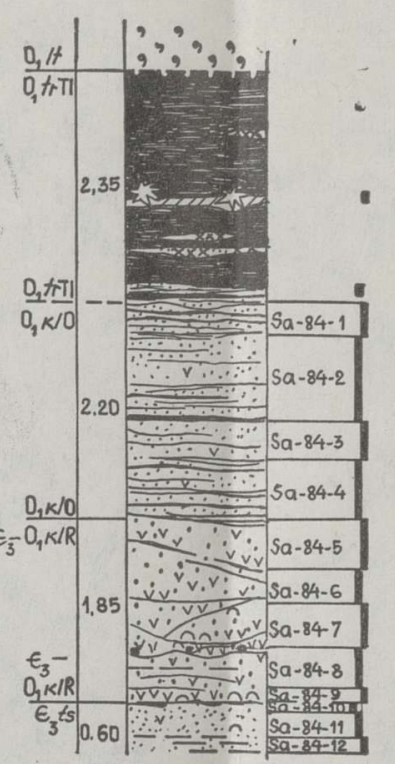

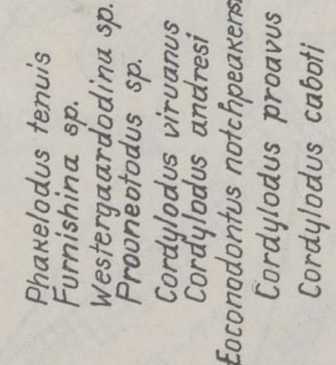



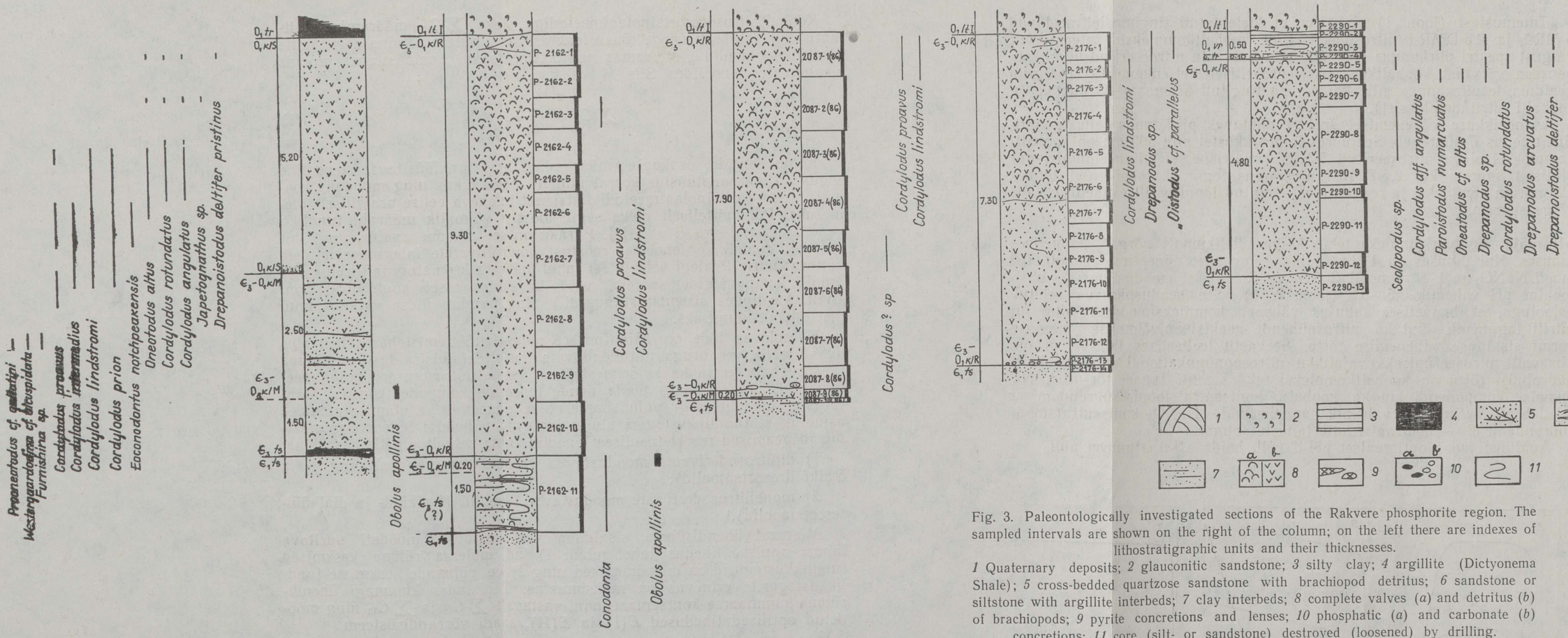

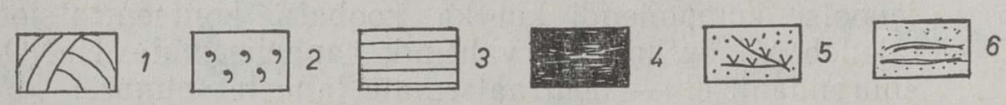

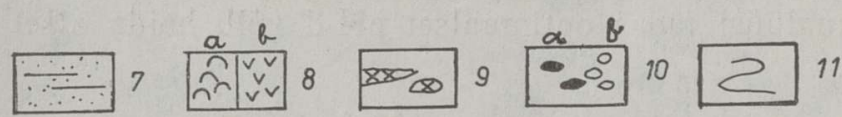

Fig. 3. Paleontologically investigated sections of the Rakvere phosphorite region. The ere lithostratigraphic units and their thicknesses. 1 Quaternary deposits; 2 glauconitic sandstone; 3 silty clay; 4 argillite (Dictyonema Shale); 5 cross-bedded quartzose sandstone with brachiopod detritus; 6 sandstone or siltst; 5 crots interbeds; 8 complete valves (a) and detritus $(b)$ concretions; 11 core (silt- or sandstone) destroyed (loosened) by drilling. 


\section{DISTRIBUTION AND LITHOLOGICAL CHARACTER OF ROCKS BY TIME INTERVALS (CONODONT ZONES)}

\section{Westergaardodina time}

The oldest among the phosphate-bearing beds under study is the late Cambrian Tsitre Formation $\left(\in_{3} t s\right)$, belonging to the Westergaardodina Zone. The formation is represented by quartzose sitstones with relatively rare clay interbeds and thin interlayers of Inarticulata brachiopod coquina, usually occurring at the base of the section.

The Tsitre Formation has been established reliably in the northeastern part of the studied territory in the Aseri-Saka area and in borehole P-2162 (to NE of the settlement of Viru-Jaagupi (Fig. 2)). The approximate distribution area of the Tsitre Formation ranges from the northeastern part of the territory to southwest between the Rakvere-Aseri and Väike-Maarja-Tudu bottom swells (Fig. 4). Tsitre sediments occur probably also in the Assamalla area, i. e. on the territory between the towns of Rakvere and Tapa and the settlement of Väike-Maarja, although this has not been proved yet by faunal data,

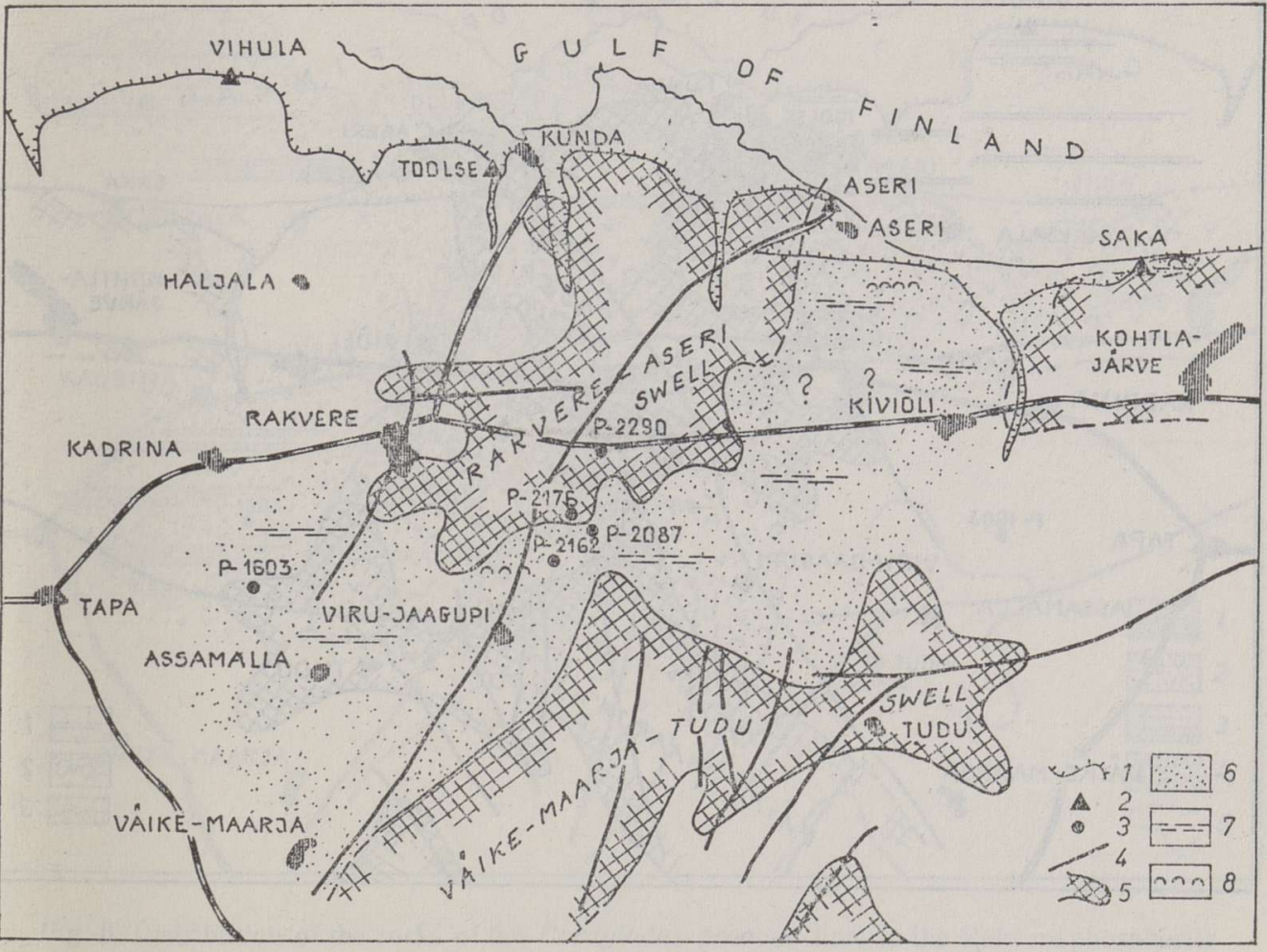

Fig. 4. Distribution of the rocks of the Westergaardodina time in the Rakvere phosphorite region.

1 North-Estonian klint; 2 outcrops; 3 boreholes; 4 tectonic disturbance zones; 5 bottom swells; 6 quartzose siltstones; 7 clay interbeds; 8 thin interlayers of brachiopod coquina. 


\section{Cordylodus andresi time}

This time is represented by the oldest part of the above-lying Kallavere Formation $\left(\mathrm{E}_{3}-\mathrm{O}_{1} k l\right)$. These beds have been established in the northwestern part of the RPR (Fig. 5) in the Vihula and Toolse outcrop sections and belong to the Maardu Member $\left(\mathrm{E}_{3}-\mathrm{O}_{1} k l M\right)$. In the Toolse outcrop the $C$. andresi Zone covers the whole Maardu Member with a thickness of $0.9 \mathrm{~m}$, which in its lower part is represented by Inarticulata brachiopod coquina ("Obolus conglomerate"), in the upper part by quartzose siltstone with interbeds of dark graptolitic argillites (Dictyonema Shale). In the Vihula outcrop the $C$. andresi Zone corresponds only to the lowermost third of the Maardu Member $(1.5 \mathrm{~m})$, composed of quartzose siltstones with dark graptolitic argillite interbeds and a thin (a few centimetres) interlayer of coquina at the base of the member.

The study of conodonts in other outcrop sections of northern Estonia has shown the sediments of the $C$. andresi Zone to be of a restricted distribution. Apart from the above-described Toolse and Vihula sections, the $C$. andresi Zone has been established also in the Turjekelder outcrop (about $30 \mathrm{~km}$ west of Viitna); outside Estonia it occurs in the Lomashka River section of the Leningrad District (Kaljo et al., 1986; Опорные разрезы ..., 1989).

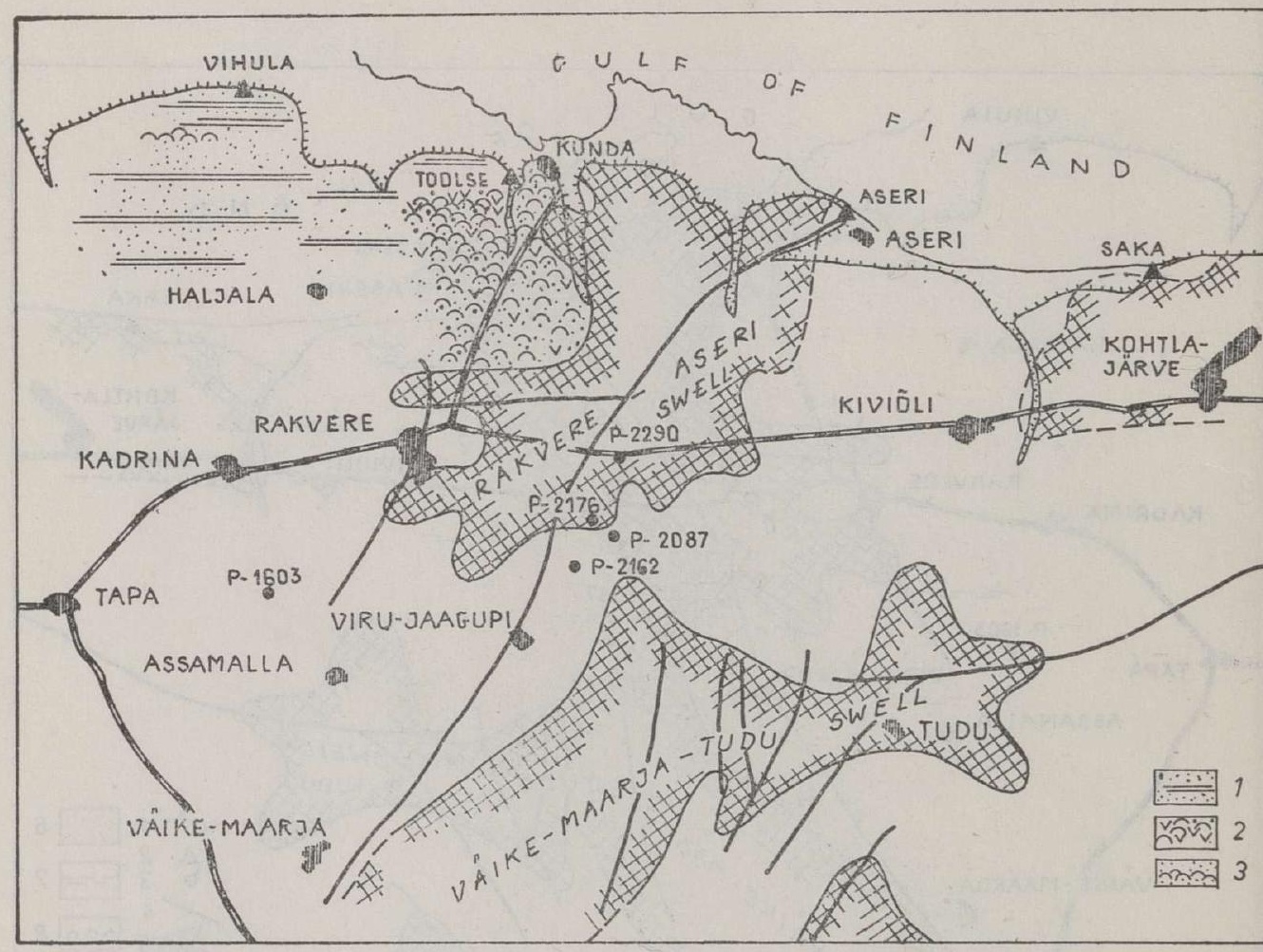

Fig. 5. Distribution of the rocks of the Cordylodus andresi time in the Rakvere phosphorite region.

1 quartzose siltstone with interbeds of dark graptolitic argillite (Dictyonema Shale);

2 brachiopod coquina of thin-walled valves; 3 thin interlayers of brachiopod coquina.

Explanation of other signs see Fig. 4 . 


\section{Cordylodus proavus time}

Compared to the underlying beds, those of the $C$. proavus Zone have a wider distribution on the territory of the RPR (Fig. 6) as well as in the whole northern Estonia. In the RPR the zone is distinguished by the index species $C$. proavus in the Vihula, Toolse, and Saka sections. In the Vihula section the $C$. proavus Zone comprises the upper $2 / 3$ of the Maardu Member (about $3.5 \mathrm{~m}$ ), represented by quartzose sandy-silty rocks with dark graptolitic argillite interbeds, and almost the whole Suurjõgi Member $\left(\mathrm{O}_{1} \mathrm{klS}, 4.5 \mathrm{~m}\right)$, composed of cross-bedded mainly medium-grained sands or sandstones with brachiopod detritus. In the Toolse outcrop the C. proavus Zone coincides with the lower half of the Suurjõgi Member, which is also represented by $1.7 \mathrm{~m}$ thick cross-bedded sands or sandstones with brachiopod detritus.

In the northeast of the RPR, in the Saka outcrop section, the $C$. proavus Zone is only $0.5 \mathrm{~m}$ thick coinciding with the lower part of the second, upper cyclite of the Rannu Member $\left(\mathrm{E}_{3}-\mathrm{O}_{1} k l \mathrm{R}\right)$, represented by brachiopod coquina (Хейнсалу, Курвитс, \& Оя, 1991). The lower cyclite (thickness $0.5 \mathrm{~m}$ ) has not yielded conodonts here. This allows of its different treatment, either as corresponding to the $C$. proavus or $C$. andresi zones, or even to the uppermost part of the Westergaardodina Zone (Хейнсалу, Вийра \& Паалитс, 1991).

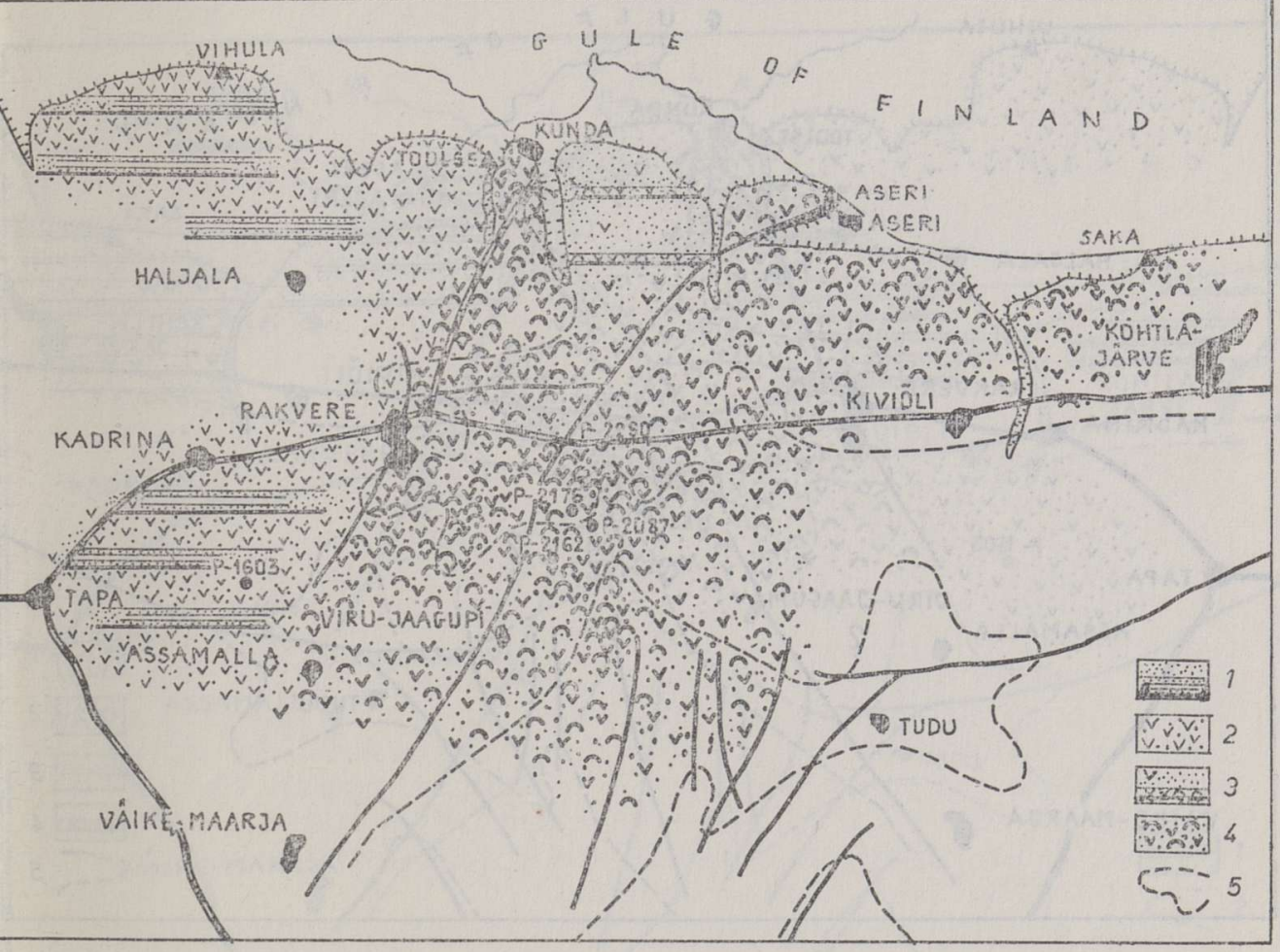

Fig. 6. Distribution of the rocks of the Cordylodus proavus time in the Rakvere phosphorite region.

1 quartzose siltstone with interbeds of dark graptolitic argillite; 2 cross-bedded sand or sandstone with relatively fine brachiopod detritus; 3 quartzose fine-grained sand or sandstone with thin interlayers of brachiopod coquina; 4 brachiopod coquina of thickwalled valves; 5 buried bottom swells. Explanation of other signs see Fig. 4. 
Conodonts are lacking also in a very thick lower part of the phosphatebearing section on the territory of the Kabala area. This area is characterized by the richest and thickest ( $6-9 \mathrm{~m}$, even up to $12 \mathrm{~m}$ ) layer of brachiopod coquina in the RPR. Therefore it is essential to establish the exact time of its formation; this, unfortunately, has not been possible by conodont data. The study of eight borehole sections has shown the absence of conodonts in the lowermost six metres of four sections. The remaining four sections with a thickness of up to $7.2 \mathrm{~m}$ were completely devoid of conodonts. They appear only in the uppermost part of the section of the Rannu Member (Fig. 3) and are already represented by the index species of the higher zones: C. lindstromi (boreholes P-2162, P-2087, and P-2176) and C. angulatus (borehole P-2290). In the sections of boreholes P-2162 and P-2087 C. lindstromi occurs simultaneously with $C$. proavus. This could serve as indirect evidence for the assignment of the lower nonconodont part of the section to the $C$. proavus Zone. This supposition is confirmed by the recovery of Obolus apollinis Eichw. (identifications by I. Puura) from the lower part of the underlying Maardu Member in the sections of boreholes P-2162 and P-1603. As is known, co-appearance of C. proavus and $O$. apollinis in the sections of the Tosna Formation $\left(\mathrm{O}_{1} t s\right)$ of the Leningrad District has been proved by the investigations of Popov and Khazanovich (Опорные разрезы ..., 1989).

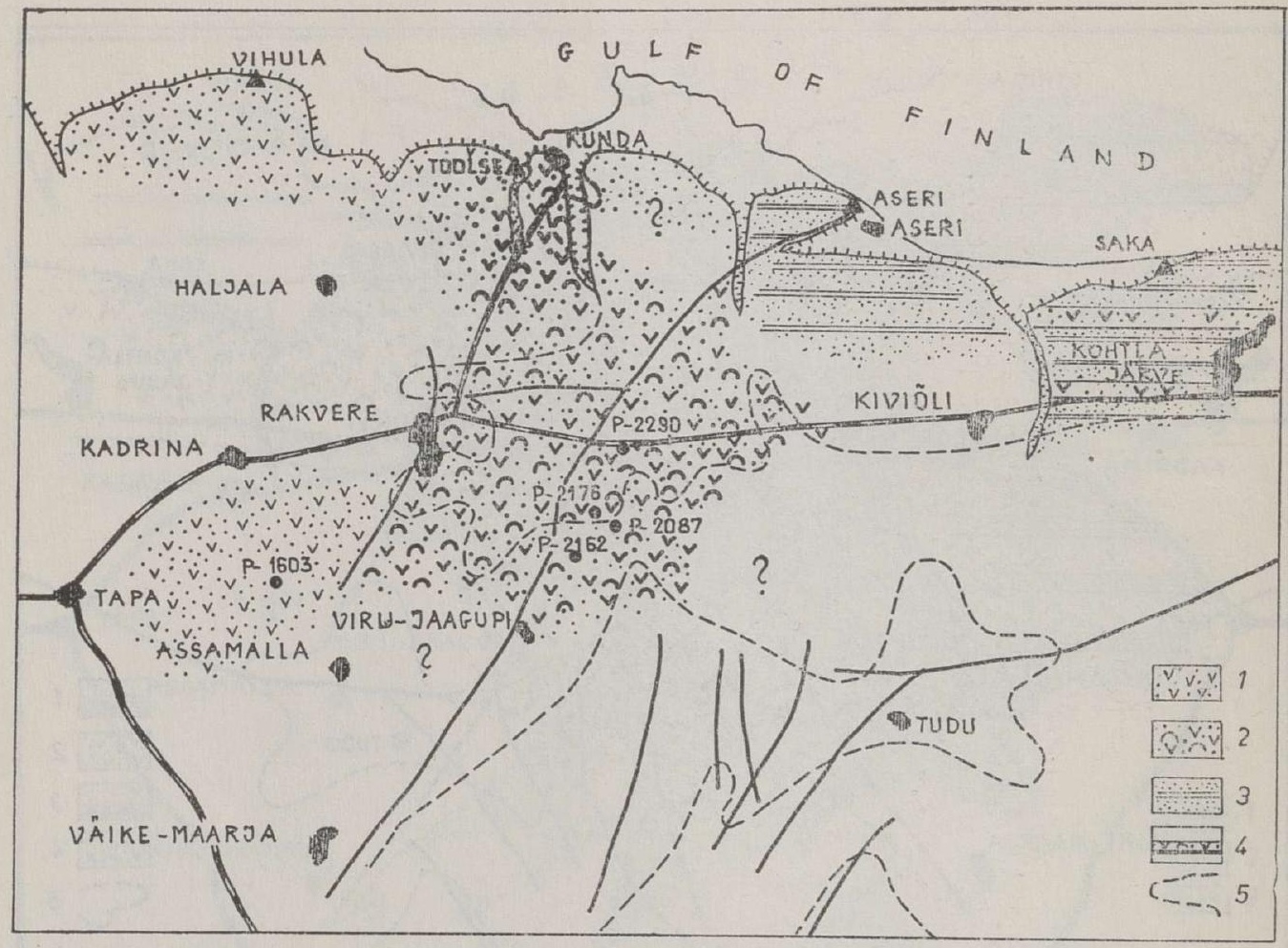

Fig. 7. Distribution of the rocks of the Cordylodus lindstromi time in the Rakvere phosphorite region.

1 cross-bedded quartzose sand or sandstone with relatively fine brachiopod detritus; 2 brachiopod coquina of thick-walled valves; 3 quartzose siltstone with interbeds of dark graptolitic argillite; 4 quartzose varigrained sand or sandstone with brachiopod detritus; 5 buried bottom swells. Explanation of other signs see Fig. 4. 


\section{Cordylodus rotundatus-C. angulatus time}

The Katela Member in the northwestern part of the RPR and the uppermost beds of the Orasoja Member in the northeastern area of the RPR (Fig. 8) correspond to the highest $C$. rotundatus $-C$. angulatus conodont Zone of the phosphate-bearing Cambrian-Ordovician boundary beds. Rocks belonging to this zone are distributed only in the northern part of the RPR. In the west they are represented by quartzose silty fine-grained sands with rare thin, mostly only $1-2 \mathrm{~mm}$ thick interlayers of graptolitic argillite (Katela Member, $\mathrm{O}_{1} k l \mathrm{~K}$ ). In the east siltstones with relatively frequent argillite interbeds of about $0.5-1 \mathrm{~m}$ in thickness (Orasoja Member) occur.

\section{DEPOSITIONAL ENVIRONMENTS}

The lithostratigraphic (Heinsalu \& Raudsep, 1993), faunal, and lithofacies analysis of the Cambrian-Ordovician phosphate-bearing boundary beds in the RPR has revealed the following aspects.

At the first stages of sedimentation during the period studied the territory of the RPR was characterized by some submarine swells with nonsedimentation or islands. The most significant among them was the Rakvere-Aseri swell. Its eastern part may have been divided into several smaller swells.

The Rakvere-Aseri swell as well as the Väike-Maarja-Tudu swell has a distinct SW-NE direction. The axis of the Rakvere-Aseri swell coincides with the present Aseri Disturbance Zone. The Väike-MaarjaTudu swell is located along the present Ahtme Disturbance Zone (Fig. 1).

The distribution of the Tsitre Formation (Westergaardodina time), constituting the oldest part of the phosphate-bearing beds studied, is outlined by the Rakvere-Aseri swell in the north and by the Väike-MaarjaTudu swell in the south. The lithology of the rocks gives evidence of a predominantly quiet hydrodynamic regime of sedimentation.

The initial stages of the formation of Kallavere sediments in the northwest of the RPR were clearly affected by the presence of the RakvereAseri swell. During the sedimentation of the deposits corresponding to the Cordylodus andresi Zone, the sedimentation margin proceeded along the western boundary of the Rakvere-Aseri swell, which at that time constituted a rather large island (or non-sedimentation area). The territory of the present Toolse deposit, immediately bordering on the island from the west, was its subaqueous slope where brachiopod valves and their fragments accumulated abundantly at the base of the Maardu Member. To the west of Toolse it was deeper and already in the vicinity of Vihula fine-grained sands and silts, sometimes also organic-rich muds, deposited. At Toolse the brachiopod coquina is represented by thin-walled and relatively well-preserved valves of Schmidtites celatus, which allows us to consider this place as their habitat. After dying out they underwent only insignificant redeposition and relatively quick burial, which could be a reason for their fairly good preservation.

At the next stage, corresponding to the $C$. proavus time, practically the whole territory of the RPR was subjected to sedimentation. The RakvereAseri and Väike-Maarja-Tudu swells turned into subaqueous elevations with intensive hydrodynamic conditions of sedimentation, which resulted in the deposition of brachiopod coquina of the Rannu Member. Phosphorite accumulation was the most intensive on the south-southeast slope of the Rakvere-Aseri swell (Kabala and Rägavere areas) and somewhat weaker on the north-northwest slope of the Väike-Maarja-Tudu swell. Such piling 
up of phosphorite could have lasted for a very short period, for instance, during a heavy storm.

During the $C$. proavus time, phosphorite accumulation on the west slope of the Rakvere-Aseri swell (Toolse deposit) took place in the form of cross-bedded sand with abundant relatively fine and well-graded phosphatic detritus of brachiopods (Suurjõgi Member).

Westwards (Vihula section) the basin became deeper, since at the beginning of the $C$. proavus time quartzose silts with graptolitic mud interbeds continued to accumulate. With time they gradually turned into fine- to medium-grained cross-bedded quartz sands enriched with brachiopod detritus, resembling the sands of the Toolse deposit. The conditions and the course of sedimentation could have been similar also further to the south, in the Rakvere-Tapa region, i. e. in the northwestern half of the Assamalla area. This assumption is based on the recovery of 0 . apollinis in the lower half of the Maardu Member (identified by I. Puura in borehole section P-1603), where it has an analogous position with the appearance of $C$. proavus in the Vihula section. At the same time in the northeasternmost Saka section of the RPR the interval of the $C$. proavus time is characterized by a $0.45 \mathrm{~m}$ thick layer of brachiopod coquina, marking only the very beginning of the transgressive cyclite, which proceeds through all the subsequent stages and ends in the accumulation of graptolite muds. The uppermost part of this cyclite corresponds already to the Drepanoistodus deltifer pristinus time.

At the following stage of the basin evolution, corresponding to the C. lindstromi time, the continuing sedimentation was analogous to that of the end of the $C$. proavus time: in the western part of the RPR quartzose fine- to medium-grained sands containing well-sorted fine detritus of phosphatic brachiopods (Suurjõgi Member) were deposited; in the central part (Rägavere and Kabala areas) mostly brachiopod coquina of the Rannu Member accumulated; in the northeastern part of the RPR the deposition of the uppermost beds of the Rannu Member in the form of rather coarse varigrained sand containing relatively small amounts of brachiopod detritus continued. Higher in the section it was replaced by fine-grained sand or silt with graptolitic mud interbeds of the Orasoja Member.

At the final stage of the Pakerort sedimentation, corresponding to the $C$. rotundatus $-C$. angulatus time, deposition was going on only in the northern part of the RPR, where quartzose sands and silts of the Katela and Orasoja members accumulated. Though the variability of these rocks is relatively low, an eastward decrease in the size of quartz grains and increase in the number of mud interbeds are still observed on the territory of the RPR, i. e. the basin deepens slightly eastwards. In the second half of the stage under consideration the sandy-silty deposits with mud interlayers of the Katela and Orasoja members are already followed by the deposition of muds containing silt interbeds of the Toolse Member.

\section{DISCUSSION AND CONCLUSIONS}

The idea about different depositional conditions of the Kallavere Formation in the western and eastern parts of northern Estonia, serving as a basis for the distinction of the western and eastern Estonian subregions, has already been expressed in earlier publications (Хейнсалу, $1981 ; 1987)$. The boundary of these subregions was supposed to lie on the territory of the RPR, but its exact position was not yet established.

The conditions of phosphorite accumulation in the RPR were also interpreted by Popov and Khazanovich (Oпорные разрезы ..., 1989), 
who compiled lithofacies maps of northern Estonia and the western part of the Leningrad District comprising the formations and subformations they had distinguished. The units established by Popov and Khazanovich differ from those fixed in the stratigraphic scheme of Estonia. According to our data, the boundaries of the units distinguished in both schemes are not synchronous. The relations between these schemes have been analysed by the present authors also earlier (Хейнсалу \& Раудсеп, 1992).

In the opinion of the authors the most important factor determining the course of sedimentation and facies differences in the CambrianOrdovician boundary phosphate-bearing beds on the territory of the RPR, was the occurrence of bottom swells of the rocks of the Lower Cambrian Tiskre and Vaki formations serving as a base for the phosphate-bearing sediments considered.

Two larger swells (Rakvere-Aseri and Väike-Maarja-Tudu) have a clear SW-NE orientation. In the axial part of the Rakvere-Aseri swell the present Aseri Disturbance Zone is located. The Väike-MaarjaTudu swell coincides in direction with the present Ahtme Disturbance Zone and its branches.

At the initial stage of the accumulation of phosphate-bearing sediments both swells were evidently islands (non-sedimentation areas). Since the Cordylodus proavus time these swells existed as submarine elevations, which were characterized by a high-intensity hydrodynamic regime of sedimentation. Phosphate accumulation was the most intensive on the slopes of these swells (Figs. 1 and 6).

On the studied territory of the RPR the greatest variability of facies sedimentary conditions was recorded at the early $C$. proavus time. At that time probably major phosphorite accumulation took place in the Kabala and Rägavere areas and also at the Toolse and Aseri deposits.

\section{ACKNOWLEDGEMENTS}

The authors are sincerely grateful to D. Kaljo for valuable comments on the manuscript, A. Noor for the translation of the paper, M. Sommer and U. Pohl for technical assistance.

The research was supported by the Estonian Science Foundation.

\section{REFERENCES}

Heinsalu, H., Raudsep, R. 1993. Lithostratigraphic subdivision of the phosphate-bearing strata $\left(€_{3}-\mathrm{O}_{1} k l\right)$ in the Rakvere area of northern Estonia. - Bull. Geol. Survey Estonia, 3/1, 4-12.

Kaljo, D., Borovko, N., Heinsalu, H., Khazanovich, K., Mens, K., Popov, L., Sergeyeva, S., Sobolevskaya, R., Viira, V. 1986. The Cambrian-Ordovician boundary in the Baltic-Ladoga clint area (North Estonia and Leningrad Region, USSR). Proc. ESSR Acad. Sci. Geol., 35, 3, 97-108.

Опорные разрезы и стратиграфия кембро-ордовикской фосфоритоносной оболовой толщи на северо-западе Русской платформы. 1989. Наука, Ленинград.

Хейнсалу Х. Н. 1981. Литология фосфатоносных отложений тремадока Северной Эстонии. Автореф. канд. дис. Таллинн.

Хейнеалу X. 1987. Литостратиграфическое расчленение тремадокских отложений Северной Эстонии. - Изв. АН ЭССР. Геол., 36, 2, 66-78.

Хейнсалу Х., Курвитс Т., Оя Т. 1991. Литолого-минералогическая характеристика стратотипического разреза раннуской пачки $\left(\epsilon_{3}-\mathrm{O}_{1} \kappa l \mathrm{R}\right)$ в Сака-II, СевероВосточная Эстония. - Изв. АН Эстонии. Геол., 40, 1, 1-7. 
Хейнсалу Х., Вийра В., Паалитс И. 1991. Пограничные кембро-ордовикские отложения разреза Сака-II в Северо-Восточной Эстонии. - Изв. АН Эстонии. Геол., $40,1,8-15$.

Хейнсалу Х., Раудсеп Р. 1992. О двух подходах к стратиграфическому расчленению тремадокских отложений Северной Эстонии. - In: Геология ракушечных фосфоритов Прибалтики. АН Эстонии, Таллинн, 100-114.

\title{
FOSFORIIDITEKKE LITOLOOGILIS-FATSIAALSED ASPEKTID RAKVERE FOSFORIIDIRAJOONIS (PÖHJA-EESTI)
}

\author{
Heljo HEINSALU, Viive VIIRA, Rein RAUDSEP
}

Mikropaleontoloogiliste uuringutega väljaselgitatud konodontide tsonaalsus on litofatsiaalsete kaartide koostamise alus. Kaardid on koostatud järgmistele konodonditsoonidele vastavate ajalõikude kohta: Westergaardodina, Cordylodus andresi, C. proavus, C. lindstromi ja C. rotundatus-C. angulatus. Kõige intensiivsem fosforiidikuhje on seotud C. proavus'e ajaga. Olulist rolli fosforiidisetendite tekkeloos on etendanud siinses basseiniosas eksisteerinud kolm kerkeala (saart?, nullsedimentatsiooniala), mille nõlvadel toimus kõige intensiivsem fosforiidikuhje. Need kambriumi ja ordoviitsiumi piirimail eksisteerinud kerkealad paiknevad nii, et nende telgjooned langevad üsna hästi kokku praeguste Aseri ja Ahtme tektooniliste rikkevöönditega.

\section{ЛИТОЛОГО-ФАЦИАЛЬНАЯ ОБСТАНОВКА ФОСФОРИТОНАКОПЛЕНИЯ В РАКВЕРЕСКОМ ФОСФОРИТОНОСНОМ РАЙОНЕ, СЕВЕРНАЯ ЭСТОНИЯ}

\author{
Хельо ХЕИНСАЛУ, Вийве ВИИРА, Рейн РАУДСЕП
}

Микрофаунистическими исследованиями на территории Раквереского фосфоритоносного района выявлены все установленные ранее в пограничных отложениях кембрия-ордовика Северной Әстонии конодонтовые зоны. Последние служат основой для расшифровки последовательности изменений литолого-фациальных обстановок осадконакопления. Литолого-фациальные карты составлены по временным отрезкам, соответствующим конодонтовым занам Westergaardodina, Cordylodus andresi, C. proavus, C. lindstromi и C. rotundatus-C. angulatus. Наибольшее фосфоритонакопление приурочено ко времени C. proavus. Важную роль в фосфоритонакоплении сыграл расчлененный рельеф подстилающих нижнекембрийских тискреских и вакиских отложений. На начальных стадиях фосфоритонакопления здесь существовало три приподнятых участка (острова?, территории нулевой седиментации), :K которым приурочено основное фосфоритонагромождение. Приподнятые участки, в свою очередь, явно тяготеют к ныне существующим Азериской и Ахтмеской зонам тектонических нарушений. 